\title{
Antropofagia, passado prático e usos do passado em Como era gostoso o meu francês (1971) de Nelson Pereira dos Santos
}

\author{
Anthropophagy, memory cultural and uses of past in How tasty was my \\ little frenchman (1971) by Nelson Pereira dos Santos
}

\section{Francisco das C. F. Santiago Júnior}

santiago.jr@gmail.com

Professor Adjunto 4

Universidade Federal do Piauí

CCHLA - Centro de Ciências Humanas, Letras e Artes

Av. Senador Salgado Filho/BR 101, s/n.- Sala 209

59078-970 - Natal - Rio Grande do Norte

Brasil

Resumo
A tradição modernista da antropofagia é uma das matrizes das imagens do passado da memória
cultural brasileira. O cinema e a cultura visual são instâncias pelas quais o conhecimento do
passado surge e circula na sociedade, este texto aponta o uso do tropo da antropofagia no filme
Como era gostoso o meu francês (1971), de Nelson Pereira dos Santos. Fundindo a tropologia
com a iconologia, observaremos a especificidade da antropofagia no início dos anos 1970
e o deslocamento do legado modernista, evidenciando o uso público do passado na narrativa
cinematográfica durante o regime civil-militar.

\section{Palavras-chave}

Cinema; Imagem; Cultura histórica.

\section{Abstract}

The modernist tradition of anthropophagy is one of the matries of the images of the past of the Brazilian cultural memory. The film and visual culture are instances in which the knowledge of the past comes and circulates in society, this text points the use of the trope of anthropophagy in the film How tasty was my little frenchman (1971) by Nelson Pereira dos Santos. Merging the tropology with iconology, we observe the specificity of anthropophagy in the early 1970s and the displacement of the modernist legacy, highlighting the public use of the past in narrative film during the civil-military regime.

\section{Keywords}

Cinema; Image; Historical culture. 
O campo cinematográfico tem suas próprias demandas quando enfrenta a elaboração de discursos e imagens do passado. Por um lado, articula uma serie de padrões e narrativas históricas presentes nas instâncias de elaboração do conhecimento da história tais como historiografia, literatura, museus, patrimônio, escultura, pintura, etc. Por outro, atualiza e desloca as tradições culturais formando imagens e saberes sobre/do passado em vários gêneros fílmicos, entre eles os chamados filmes históricos. Este texto almeja demonstrar a relação de um "filme histórico", no caso Como era gostoso o meu francês (1971), de Nelson Pereira dos Santos, com as imagens do passado brasileiro herdadas da antropofagia modernista. Entender a maneira como o campo cinematográfico se relaciona com o passado permite abordar os usos públicos deste na cultura visual.

A fita de Santos foi elaborada num momento chave de apropriações sociais do passado brasileiro. No auge repressivo da ditadura civil-militar, muitos cineastas, principalmente os remanescentes do cinema novo, realizaram filmes históricos que partiam ou enfrentavam o legado modernista. A ideia da incorporação dos recursos culturais e materiais estrangeiros como forma de resistência retornou em fitas como Dragão da Maldade contra o Santo Guerreiro (1968), de Glauber Rocha, Macunaíma (1969), de Joaquim Pedro de Andrade e O Bandido da Luz Vermelha (1968), de Rogério Sganzerla. Nos filmes históricos esse mesmo princípio fora retomado, principalmente nas fitas que tematizaram o passado 158 indígena entre as quais citamos Pindorama (1971), de Arnaldo Jabor, e Como era gostoso o meu francês (1971). Esta última película usa imagens e metáforas do passado para discutir a relação presente e passado e permite observar como a esfera pública elaborou alguns passados possíveis com implicações políticas específicas.

Trabalhos recentes sobre as "representações históricas no cinema" têm demonstrado que haveria uma operação cinematográfica de visualização da história, sujeita a regras, narrativas e lugares institucionais próprios da produção fílmica (LINDPERG 2009). Mais do que filmes que representam/ plasmam a história em imagens (ROSENSTONE 2010), tem-se usos do passado em circuitos sociais cuja dimensão é pública ao ser midiática e massificada. ${ }^{1}$ A produção de filmes é uma maneira pela qual o conhecimento do passado é apropriado e modificado em campos culturais exógenos à historiografia. Tornase, por tabela, um dos campos fundamentais de configurador da memória do século XX (BAECQUE 2012; SHOHAT; STAM 2004).

A problematização da história da cultura visual indaga pelas formas visuais e as maneiras como estas fazem a realidade social funcionar (MENESES 2004; MITCHELL 2009), ou seja, como os sujeitos usam das imagens para encontrarem

\footnotetext{
${ }^{1}$ Os "usos do passado", como exposto acima, deriva da preocupação com os "usos públicos da história", um dos tópicos de uma teoria da história mais abrangente. Corresponde ao que Rafael Saddi defendeu, a partir da Didática da História de Jörn Rüsen, como investigação "da consciência histórica produzida nos meios de comunicação de massa (revistas, jornais, televisão, cinema, propagandas, sites), bem como nos discursos políticos [...] e também nas instituições culturais e religiosas [...]" (SADDI 2012, p. 217).
} 
seus passados, suas comunidades, seus vínculos e diferenças entre $\mathrm{si}^{2}$. Entre os historiadores da cultura visual, fica cada vez mais claro que a imagem passa a ser concebida como fundamento da própria historicidade do presente e do passado. Ao que tudo indica a pedagogia material e visual e as organizações de instâncias visuais como monumento, museu, fotografia e cinematógrafo (CHOAY 2011; GUIMARÃES 2002; MENDONÇA 2008; MIRZOEFF 1999) formaram e formam a historicidade moderna.

Podemos dizer que tais os usos públicos do passado (SADDI 2010) são foco de preocupação de uma analítica da historicidade (ARAÚJO 2013), ou seja, como a experiência da história transforma o passado em um bem da disputa social sujeito a demandas próprias geradas em muitos campos sociais - como o cinema. O problema da constituição de imagens do passado contempla os múltiplos meios sociais que elaboram conhecimento e representações sobre ele e o publicizam.

Frequentemente, fazendo parte do movimento da memória pública, os filmes encontram a história já mediada por meio de usos de imagens e tropos (metáforas, metonímias, ironias e etc.), tendo a interpretação do passado no cinema, portanto, um forte teor poético. Tomamos como princípio de trabalho, que a imaginação histórica fílmica usa de recursos de imagens \& tropos (figuras de linguagem), para construir sua interpretação do passado. Sua poética refere-se ao cruzamento das interpretações tradicionais do passado presentes na memória cultural com as possibilidades de construí-lo como imagem num dado presente histórico.

Nos últimos anos muitos estudiosos têm refletido sobre a construção da historicidade pelo cinema (MORETTIN 2012). Antoinde Du Baecque (2012), por exemplo, explorou as formas cinematográficas da história, maneiras visuais singulares pelas quais o transcorrer e o passado foram configurados na forma memorial-cinema e o próprio registro fílmico articulando formas/figuras do presente, os quais, retomadas no futuro funcionam como um arquivo das imagens do passado. Também Vicente Sanchéz-Biosca (2014) refletiu sobre a chamada migração de imagens, um processo pelo qual o misto registro/encenação de imagens de tortura produzidas por perpetradores ou por libertadores, estabelece algo como protocolos formais e arquivos usados como mediação na configuração da memória cultural por meio do cinema e fotografia. Ambos evidenciam um tipo de conhecimento que é tanto verbal quanto visual.

Seguindo a distinção estabelecida por Michael Oakeshott entre passado histórico e passado prático, Hayden White propõe que este último como o conjunto de:

[...] noções de "passado" que todos carregamos conosco em nossas vidas diárias e às quais recorremos, quer queiramos ou não, da melhor forma possível, como informação, ideias, modelos, fórmulas e estratégias para resolver todos os problemas práticos - de assuntos pessoais a grande

\footnotetext{
${ }^{2}$ Estamos generalizando propostas de trabalhos variadas como a antropologia da imagem, a iconologia, história social da arte e a ciência das imagens. Todas, contudo se aproximam quanto ao princípio da cultura visual e da imagem como formadoras do mundo social.
} 
programas políticos - reunidos de qualquer jeito no que concebemos como nossa "situação" atual. Baseamo-nos neste passado sem muita consciência de si mesmo quando se trata de questões práticas [...] Mas este passado prático é também o passado da memória reprimida, do sonho, do desejo tanto deste quanto da resolução de problemas, estratégias e táticas do cotidiano, tanto pessoal como comunitário (WHITE 2014, p. 181). ${ }^{3}$

Perceba-se que o pratical past de Oakeshott lido por White corresponde, de alguma forma, a um aspecto do "espaço da experiência" elaborado por Reinhardt Koselleck, enquanto Jörn Rüsen o chamaria de conjunto de orientações para a vida prática que compõem as funções do conhecimento histórico na matriz disciplinar da história. Já o passado histórico seria construído por instâncias sociais de elaboração de um tempo comunal desenvolvido e organizado institucionalmente, tendo caráter mais ou menos disciplinar e podendo ser construído com teoria e método para o entendimento do presente. Os cineastas montariam, por exemplo, suas interpretações mobilizando noções de passado públicas encontradas em diversas mídias, acionando o passado prático. Contudo, intuir que um cineasta mobilize - como qualquer pessoa faz - o passado prático oferece apenas uma aproximação incompleta: é preciso deslocar a interpretação de White, que supervaloriza a diferença passado prático/passado histórico.

O passado prático só pode ser acionado por sua presença na memória cultural, ou seja, nas heranças armazenadas em textos, tradições, imagens, ritos, monumentos, celebrações e toda sorte de suportes mnemônicos que funcionam como armazém/arquivo que permite a mobilização de significados (ASSMANN 2009). A antropofagia modernista, como veremos, é um tropo, um desvio de sentido primeiro presente nas tradições modernistas usadas para mediar a relação com o indígena e o passado remoto do Brasil (STAM 1997). O interesse pelo tropo aqui não é mero retorno à tropologia, mas ampliação de suas possibilidades pela iconologia (MITCHELL 2009, p. 211). Interessa-nos o caráter acional contido no recurso ao tropo modernista que permitiu a alguns sujeitos compreenderem seu passado e agenciá-lo como cinema. O campo cinematográfico promove o encontro de textos verbais, visuais e artefatos históricos disponíveis na sociedade brasileira, em relação aos quais os sujeitos se posicionavam num dado contexto. A narração cinematográfica se apropria deles como forma de experimentação da historicidade.

\section{Como era gostosa a ironia}

A fita Como era gostoso o meu francês realizou uma inflexão nas interpretações do período colonial vigentes nos mitos modernistas aos quais retoma. Partindo da imagem do indígena tal como aparecia nos textos dos modernistas, o diretor Nelson Pereira lançava-se nos filmes históricos para

\footnotetext{
${ }^{3}$ No original: "[...] notions of the 'past' which all of us carry around with us in our daily lives and wich we draw upon, willy-nilly and as best we can, for information, ideas, models, formulas, and strategies for solving all the pratical problems - from personal affairs to grand political programs - met with in whatever we clonceive to be our present 'situation'. We draw upon this past without much self-consciousness when it comes to pratical matters [...]. But this practical past is also past fo repressed memory, dream, and desire as much as it of problim-solving, strategy, and tactics of living, both personal and communal".
} 
criar soluções de participação social num momento de política autoritária. A fita retomou o Manifesto Antropófago (1928) de Oswald de Andrade, no qual se presumia que a deglutição do estrangeiro e sua assimilação cultural deveria ser a marca da vivência/projeto histórico nacional no início dos anos 1970.

Como era gostoso o meu francês foi lançado em circuito comercial nacional finais de 1971. Produção que usava como base a narrativa Viagem ao Brasil (1557), do alemão Hans Staden, marinheiro luterano que quase fora devorado pelos tupinambás no século XVI, propôs-se a fazer uma reconstituição de época minuciosa possível, tomando, inclusive, várias opções etnográficas: todos os indígenas andam nus; a língua falada foi o tupi e a fita foi exibida nos cinemas com legendas; a reconstituição de rituais tentou seguir não apenas as narrativas da época, mas observações etnográficas contemporâneas ao filme, entre elas textos sociológicos e históricos contemporâneos.

O roteiro tinha particularidades: o protagonista Jean era francês; o personagem termina a fita sendo devorado, ao contrário do herói de Viagem ao Brasil; o filme intercala relatos de vários viajantes do século XVI (além do de Staden $^{4}$ ) com as imagens filmadas, criando um confronto entre fontes históricas e encenação cinematográfica. A proposta da fita visava construir a identificação do espectador com os indígenas e não com o europeu, de maneira a intuir que o exemplo do "brasileiro original" seria o índio antropófago, tal como concebido pelo modelo modernista.

No início da fita, uma voz over ${ }^{5}$ lê a carta que o francês Durand de Villegaigon escreveu para João Calvino, em 1557, contando o sucesso da instalação de uma comunidade calvinista, nas terras do Rio de Janeiro. Villegaigon requisitava missionários sobre o pretexto de que a colônia era uma terra de convivência religiosa pacífica. O autor da carta, porém, fora um tirano, como mostra o relato divergente de Jean de Léry uma vez que Villegaigon expulsou muitos missionários protestantes - para depois ser expulso pelos portugueses. A voz over afirma ainda que os indígenas eram bestiais, selvagens, sensuais e primitivos, enquanto os colonos seriam o oposto; contudo, a imagem mostra nativos educados e europeus assediando mulheres indígenas.

Como chamaram atenção Stam (1997) e Sadlier (2012) o uso dos documentos históricos na fita era irônico, pois as cenas apresentavam a hospitalidade indígena contraposta ao relato histórico que os bestializava. 0 filme desmentia a tolerância entre colonizadores, os quais viviam matando uns aos outros. Os tupinambás eram aliados dos franceses e inimigos dos tupiniquins, aliados dos portugueses. Jean, fugindo de Villegaigon, foi capturado pelos tupinambás e confundido com um português, passará por oito meses de incorporação à vida na tribo para enfim ser devorado ritualisticamente e sua força absorvida pelos indígenas.

\footnotetext{
${ }^{4}$ Além de Hans Staden são exibidos, sempre em fundo preto, trechos de relatos do Abade Thévet, Padre Anchieta, Pero de Magalhães Gandavo, Jéan de Léry, Padre Nóbrega e Mém de Sá.

${ }^{5}$ Voz over é a narração oral que acompanha a imagem, mas cuja fonte não está disponível na imagem. No caso dos documentários, é chamada de "voz de Deus", pois provem de lugar algum. A voz over do filme de Santos, porém, usa uma elocução de programa radiofônico, inserindo um elemento anacrônico e cômico, não tendo, portanto, nada de um narrador superior à trama mostrada.
} 
Originalmente o canibalismo foi uma metáfora ocidental que fez parte das montagens de outros fantasmáticos (sob os predicados de pagãos, bárbaros, primitivos e uma serie de adjetivação do "outro" (STAM 1997), terminando, contudo, por transformar o próprio ocidente em fantasma de si (KIENING 2014). Apesar das tentativas de relativizar o barbarismo e diferenciá-lo do canibalismo, tal como no ensaio Os Canibais, de Montaigne, no século XVI, o canibalismo só seria interpretado positivamente pelas vanguardas modernistas, quando passaria a ser empregado como um tropo de insurgência estética. O dadaísmo e seu Manifesto Cannibal Dadá, de 1920, do espanhol Francis Picabia, lido no Théâtre de la Maison de I'Ouvre, em Paris, começou a celebrar a metáfora da ingestão, do devorar o outro não para incorporá-lo, mas para eliminá-lo. A ligação do dadaísmo com o primitivismo acentuava a subversão do canibalismo numa renovação interior do artista, interessado em ser herético e desafiar as convenções artísticas sociais da burguesia e descendentes das velhas aristocracias europeias da época (GAY 2006).

Já versão modernista brasileira remetia ao uso do tropo no indianismo romântico, quando os relatos dos cronistas coloniais foram reinterpretados como se pode observar em Ubirajara (1874), de José de Alencar, e no poema I-Juca Pirama (1851), de Gonçalves Dias. Segundo José Castro Rocha, as obras destes românticos apontavam para o canibalismo indígena "como uma visão de mundo determinada" (ROCHA 2001, p. 649), tendo Alencar, por exemplo, antecipando muitos dos elementos tratados por Oswald de Andrade. Conhecedor das propostas sobre o primitivo nas vanguardas europeias, o poeta decidiu pensar-se primitivo e incorporar os ditos civilizados. Deslocava-se assim o eixo de Montaigne (que estava interessado em usar os americanos para falar de si) sobre os indígenas do Brasil, uma vez que Oswald de Andrade e outros realizaram uma desleitura 6 da metáfora do canibalismo. A antropofagia modernista implicava em devorar técnicas, temas e informações estrangeiras e incorporá-las de maneira tática. Assim como os tupinambás devoraram seus inimigos para incorporar sua força, argumentava-se que os brasileiros deveriam devorar a cultura estrangeira e produzir nova síntese. O canibalismo nunca dera origem a um movimento ou a uma estética própria entre as vanguardas europeias sendo apenas uma das opções de metáforas nos movimentos já existentes. Já no Brasil ocorreram desvios de significado do material europeu e romântico brasileiro numa inversão produtiva das forças simbólicas (e práticas) da dominação em formas internas de insurreição.

No primeiro modernismo, a antropofagia incorporou o canibalismo como imagem/ideologia estética positiva. Após certo hiato durante os anos 1930-40, a antropofagia voltou à baila na vanguarda literária em meados dos anos 1950, quando os poetas concretistas retomam as propostas formais dos modernistas

\footnotetext{
${ }^{6} \mathrm{~A}$ trabalhada neste texto de desleitura é um ato de ressignificação no qual ocorre um uso de tropo que permite observar a apropriação de imagens e tropos anteriores e evidenciam o posicionamento de um sujeito frente a (retomada da) tradição visual e verbal. Remete a obra de Bloom, mas não é a mesma do crítico (Cf.: BLOOM 2003).
} 
como uma base para produção/reflexão da forma poética. ${ }^{7}$ Nas artes plásticas, tanto os concretistas como os neoconcretistas (estes de 1959 em diante) criaram um diálogo entre poetas, literatos e artistas plásticos no qual Oswald e a antropofagia foram cada vez mais reivindicados como definidores da prática estética e da vanguarda cultural. Em meados dos anos 1960, no "movimento" da Tropicália, a incorporação de estéticas estrangeiras e o entrecruzamento de referências estéticas nacionais variadas (cultura popular e erudita, etc.) tinham o fim de burlar os limites entre o aceito e não aceito pela vida cultural brasileira.

As diversas operações antropofágicas desse período foram desleituras de sujeitos definidos, maneiras de apropriar-se para dizer outra coisa numa corrosão de dicotomias fáceis (nacional/estrangeiro; popular/erudito) e na ideia de que o próprio corpo e a arte construíam utopias de emancipação coletivas e/ ou subjetivas em possibilidades estéticas e políticas (FAVARETTO 2007). Oswald de Andrade reapareceria no debate cultural nas reações à recepção de Terra em Transe (1967), fita de Glauber Rocha, mas especialmente após José Celso Martinez adaptar a peça daquele, O Rei da Vela (1967), a qual reorganizou o debate ao redor de temas oswaldianos (JENIZZI 2010). Fitas como Dragão da Maldade contra o Santo Guerreiro (1968), de Glauber Rocha, e principalmente Macunaíma (1969), adaptação do clássico de Mário de Andrade por Joaquim Pedro de Andrade, além de O Bandido da Luz Vermelha (1968), de Rogério Sganzerla evidenciam como nesta época a antropofagia tornou-se patente no cinema, e tanto nos cinemanovistas como no nascente "cinema marginal" o incorporar/ devorar a estética estrangeira original virou incorporação de alteridades imprevistas (estrangeira e das diversas expressões culturais nacionais) para burlá-las umas das outras como resistência estética.

Nos filmes de temática histórica, porém, ocorreram retornos ao passado colonial marcados pela presença dos indígenas, os quais produziram uma (re)visão da antropofagia em sua origem canibal e histórica, numa diferença fundamental em relação a antropofagia performática e temática que marcava produções do cinema marginal, e, em larga medida do Macunaíma de Joaquim Pedro. ${ }^{8}$ Fitas como Pindorama (1971), de Arnaldo Jabor, e Como era gostoso o meu francês (1971), de Nelson Pereira dos Santos, retrataram o período da chegada dos europeus e os mostraram enfrentando o "selvagem" canibal em uma representação icônica. Neste momento a antropofagia retornava à figuração em chave etnológica e outra desleitura seria realizada.

\section{Invertendo a ironia}

Alguns analistas advogam que Como era gostoso o meu francês faria eco às resistências de certos setores da sociedade brasileira contra as multinacionais (SHOHAT; STAM 2006; SADLIER 2012). O canibalismo indígena denunciaria as práticas econômicas do colonialismo exploratório e propunham que os brasileiros

\footnotetext{
7 O Manifesto Concretista é de 1956, publicado na Revista Ad, São Paulo (Cf.: CAMPOS 1987).

${ }^{8} A$ antropofagia como performance é foco de outro texto do autor, em desenvolvimento. Os filmes históricos nos quais a antropofagia era chave na encenação pretendiam e ocupavam o lugar do monumento cultural, diferente da performance antropófaga que poderia se esgotar na obra como ato efêmero.
} 
imitassem os tupinambás para resistir aos colonizadores. Esta interpretação, porém, estabelece uma alegoria que não enfrenta a relação da fita com as tradições e com as fontes históricas no entrelaçamento entre imagens e textos na fita.

Logo após a cena inicial da voz over de Villegaigon e subsequente fuga de Jean, os créditos da fita são apresentados sobre as gravuras de Theodore de Bry, realizadas a partir dos relatos de Hans Standen e Jean de Léry. De Bry fora um protestante que montara a coleção visual Thesaurus de Viagens ou Collectionnes Peregrinatorum in Indiam Occidentalem et Indian Orientalem, publicado em 13 volumes entre 1590 e 1634. Na terceira parte desta coleção, Americae Tertia Pars, de 1592, estão as imagens sobre as narrativas da ocupação da França Antártica, baseadas nos textos de Staden e Léry (CHICANGANA-BAYONA 2006). De Bry construíra o seu tupinambá canibal a partir do ideal renascentista do homem vitruviano sendo o único critério de diferença os adereços, os hábitos retratados e a cor da pele. Essas imagens foram associadas aos relatos de Léry e Staden nos séculos seguintes.

Importante observar que Santos escolheu abrir o filme com ilustrações as De Bry e não com os desenhos originais contidos na edição de Hans Staden. ${ }^{9}$ As imagens que abrem Como era gostoso o meu francês mostram várias gravuras dos hábitos canibais, as quais ressaltam detalhes de grelhas, corpos desmembrados caldeirões, gozo indígena no ritual macabro e membros sendo comidos. O texto de Hans Staden transformou o canibalismo numa lógica ritual da vingança na qual a autenticidade, a alteridade e a subjetividade abordam o tópico da incorporação tanto cultural como física. No filme, porém, o contraponto era outro, pois os relatos europeus foram intercalados com cenas que desmentiam ou contrapunham atos e acontecimentos ao que era informado pelos textos. Tais excertos, como notas de rodapé fílmicas, estavam dispostos na narrativa de maneira a cumprir, de certa forma, o papel ocupado pelas ilustrações no texto de Staden, só que de maneira irônica.

Na tradição literária ocidental, os episódios de ingestão humana podem ser encontrados desde a Odisseia (GAGNEBIN 2006) e o ocidente herdou o topos literário da ingestão como uma forma de diferenciar seres humanos dos nãohumanos. O realce visual da barbárie e selvageria das ilustrações de De Bry, as quais estavam na base da instituição dos mitos do selvagem americano, foram produzidos do ponto de vista fantasmático: em meio às possessões maravilhosas, havia os terríveis canibais prontos a comer os estrangeiros. Em especial, a partir do Renascimento a elaboração do conceito de humanidade usou do canibalismo como um atributo do selvagem, um tropo da desumanização que consistia em definir o homem de maneira negativa: "é o que o animal e o divino não são" (WHITE 2001, p. 207). ${ }^{10}$ Os meios-termos eram da classe dos "selvagens", parentes dos animais e dos monstros (LESTRIGANT 1997).

\footnotetext{
${ }^{9}$ Duas viagens ao Brasil originalmente fora publicado ilustrado, não por De Bry, mas com inúmeras xilogravuras realizadas por algum artista que não o próprio Staden (segundo a maioria dos estudiosos), mas que foram compostas sobre sua orientação. A edição de 1941, que circulava no Brasil e a qual Nelson Pereira dos Santos deve ter tido acesso, continha os desenhos originais.

${ }^{10} \mathrm{~A}$ selvageria era composta pelo uso de cinco princípios fundamentais para constituir a metáfora da desumanização: nudez, comunhão de propriedade, anomia, promiscuidade sexual e canibalismo (Cf.: WHITE 2001).
} 
Pela ironia se deslê a desumanização em Como era gostoso meu francês. Os usos de fontes históricas pela narração fílmica relativizam a selvageria histórica dos indígenas a partir da violência europeia. Os indígenas são apresentados a partir de um olhar etnológico (SANTIAGO JR 2014), uma espécie de etnografia visual encenada na qual mostra-se as técnicas corporais, hábitos e mitos, conferindo-Ihes certa racionalidade selvagem na qual a violência do nativo é reativa e ritualizada. Todos os atos de violência cometidos pelos europeus são motivados individualmente, seja por desconfiança, vaidade ou ganância. Também é na imagem que fica evidente como os europeus eram desprovidos de vínculos solidários, afinal são dois franceses, em um determinado momento, que lutam e se matam pela posse do ouro depois de exumarem um túmulo nativo - como contraponto o túmulo havia sido apresentado cenas antes com todo respeito por Seboipepe a Jean. Este último mata um conterrâneo que o ajudaria a fugir da América.

A ironia é o tropo dominante na fita, servindo não apenas para criar outra impressão do indígena, mas também para ampliar a força de outro tropo, o da antropofagia. Por meio da interpretação irônica das fontes históricas, a atribuição de selvagem ao indígena entra em crise e surge um modelo de "civilidade" americana, enquanto os franceses, aos quais se atribuiria a civilidade, têm suas significações desviadas, "girados" em selvageria. Este deslocamento retórico seria tópico da tropologia não fosse fato de que a civilidade indígena advém ao espectador como apresentações visuais de sua cultura imaterial e material, suas técnicas corporais, as quais, em sua maioria, têm significados indefinidos para o espectador.

Caberia à imagem definir, por meio das técnicas do corpo artefatos e objetos simbólicos (cuja semântica exata escapa aos espectadores) gravadas pela câmera a alteridade da cultura e tempo tupinambás. Os indígenas são mostrados como uma cultura dotada de sentido, um texto se poderia dizer, mas um texto que é majoritariamente visualizado e tem boa parte de seus significados lançados na opacidade. O indígena aparece mediado pelos elementos antropológicos, os quais foram apropriados pelo campo cinematográfico pela atitude do diretor, como o próprio Nelson Pereira afirmara:

O fato de situar a história no século XVI [...] não invalida a análise do choque cultural entre duas culturas em estágios diferentes. Ou mais precisamente falando, de um ponto de vista econômico, do choque entre dois povos um subdesenvolvido e outro desenvolvido [...] Tive, assim, de reconstituir um passado longínquo um passado, o que implicou num a interpretação pessoal da História. Toda preparação do filme, por exemplo, foi estrutura sobre elementos antropológicos. Respeitei todos os dados disponíveis da cultura tupinambá existentes no Brasil. A interpretação das relações entre tupinambás e o europeu foi muito pessoal (SANTOS 1970 p. 16, grifos nossos).

Nelson procura o ponto-de-vista do "outro" e incentiva uma interpretação alegórica do filme ao juntar numa mesma sentença a consideração sobre o respeito aos "elementos antropológicos", os quais garantem a opacidade 
histórica da fita e uma leitura anacrônica do "choque de dois povos um subdesenvolvido e outro desenvolvido". Isso aponta para um uso do passado mediado, evidentemente, por elementos do presente, como o debate corrente nos anos 1960 e 1970 entre subdesenvolvimento e desenvolvimento, ou o desejo de descolonização da cultura brasileira. Mas a mediação com o presente aplica interpretações anteriores sobre a presença histórica indígena no Brasil, no caso o mito modernista da antropofagia. A vida nativa na película é um mostruário da vida humana na América ancestral, uma encenação do mito da origem cujos significados são observados em distância etnohistórica. Encenados como outro e ancestral, dotados de sua própria diferença cultural e temporal, os indígenas são apropriados pelo filme como ícone mediado pela antropofagia.

Para um espectador a tradição é encarada dentro da zona intemporal da sala de cinema, mas diretores-roteiristas-encenadores estão condenados, no momento da realização da fita, a trabalharem dentro de seu tempo e história, principalmente no caso das tradições terem "dito" ou mostrado tudo aquilo que seja considerado o caso de se dizer sobre um dado motivo. Enfrentar a memória tupinambá e seu canibalismo histórico, encenando-a na diferença cultural/história significava, no início dos anos 1970, travar um encontro com as interpretações canônicas da cultura brasileiras sobre o tema, principalmente aquelas já ressignificadas pela tropicália. O canibalismo aqui cumpre o papel chave nesse confronto com a memória cultural, pois, na medida em que a retomada do texto de Staden foi realizada em chave antropofágica, Como era gostoso o meu francês cria um "giro" nesta mesma tradição.

A antropofagia, cumpre lembrar, é uma metáfora montada como resposta brasileira ao imaginário europeu que espelhava o americano como outro fantasmático negativo (o devorador bárbaro à Staden) ou positivo (o bom selvagem, de Montaigne). O canibalismo, no passado, operava como uma figura que transformava o perigo ameaçador da absorção da identidade social e da integridade corporal em um lucro enfático de significado com múltiplas possibilidades de denominação e conexão. Segundo Kiening (2014), como tropo metonímico, pelo menos desde Staden, o canibalismo aponta as relações sociais complexas entre indígenas e destes com os conquistadores, perspectivando a cultura um do outro. Como tropo metafórico abria novas opções, tornando visíveis as qualidades do estranho (indígena) no próprio (colonizador), a violência que espreita a proximidade direta e o jogo de trocas entre práticas e encenações de poder, modificando, por tabela o olhar sobre o familiar. Em Como era gostoso o meu francês, o canibalismo brasileiro era uma expressão da cultura, enquanto as atrocidades europeias foram transformadas em uma recaída no animalesco. A antropofagia é, portanto, irônica quando considerada em relação a sua matriz europeia, como uma metonímia e/ou metáfora de nacionalidade para o contexto brasileiro entre 1920 e 1960. Com ela se romperia a especulação da alteridade europeia por meio da identidade nacional que incorpora (metaforicamente) e resiste ao estrangeiro. A antropofagia foi o primeiro arcabouço tradicional de uso do passado do qual o cineasta Nelson Pereira dos Santos se serviu para enfrentar a imaginação histórica do indígena brasileiro. 


\section{Além da antropofagia tropicalista}

Em suma, para Nelson Pereira dos Santos, a antropofagia era parte da tradição, uma classificação e matriz da memória cultural que mediava o passado à qual o cineasta acrescenta sua própria contribuição ao cruzar vestígios históricos (relatos e imagens de época) e reconstruções ficcionais. A película foi interpretada como uma alegoria histórica, ou seja, as lutas indígenas contra os europeus seriam espelhamentos de resistências do presente, correspondendo, neste sentido, Como era gostoso o meu francês, a um ato ideológico descolonizador. Na época do lançamento do filme a interpretação em chave antropofágica enfatizava a tensão entre culturas diferentes (os indígenas e os europeus):

Este quadro antropofágico é ao mesmo tempo um relato fiel dos conflitos entre brancos e índios no Rio de Janeiro de quatro séculos atrás e uma fiel imagem dos conflitos entre senhores e escravos. No momento em que as pessoas descobrem que muito da harmoniosa ligação entre os homens e a paisagem foi destruída por hábitos adquiridos pelo mundo civilizado, Como era Gostoso o Meu Francês vai ao centro da questão do olhar o conflito entre os colonizadores europeus e os índios a partir do ponto-de-vista dos tupinambás (AVELLAR, 1972, grifos nossos).

A leitura de José Carlos Avellar reforça, a partir da "fidelidade" à concepção etnohistórica da fita, um horizonte de consciência histórica na qual o cinema, mais do que encenar cria uma visão do passado. Porém, as informações históricas "fieis" foram interpretadas numa lição moral antropofágica. Também Orlando Fassoni (1972) lembrava que a película deveria ser vista a partir do "conceito novo de que cabe aos fracos comerem os fortes, antes que sejam por estes devorados".

Contudo, a escolha da fita não fora pela metáfora antropofágica simplesmente, mas pela antropofagia histórica, o canibalismo. O quarto final do filme é composto de três sequências nas quais a apresentação do olhar etnológico encontra com a antropofagia modernista. Como chamou atenção Lúcia Nagib (2006), a bela cena na qual Seboipepe explica a Jean como decorrerá sua morte é a preparação para o clímax ritual: o que poderia ser desesperante culmina num grande gozo. A indígena gesticula, derruba Jean no chão, mostra como seu corpo será cortado, imitando os golpes que o mutilarão. O canibalismo no texto de Staden, por exemplo, era marcado pela mutilação e tem sido comum nos relatos europeus a cena da tortura e do despedaçamento sacrificial do corpo (CHICANGANA-BAYONA 2006). Contudo, Seboipepe instaura nova inversão na representação do selvagem ao contrariar os topoi comuns nas narrativas canibais: a índia explica a Jean que este deve morrer tentando lutar (porque deve demonstrar ser um guerreiro valente e não uma vítima) enquanto o seduz.

Durante a sequência, com o amante deitado no chão, Seboipepe estende seu corpo sobre o de Jean e leva a boca ao seu pescoço, que será o seu "bocado" depois de cozido, e lá o morde dando início à finalização da cena com 
os dois personagens fazendo amor na pedra litorânea e paradisíaca na qual se encontram. ${ }^{11} \mathrm{O}$ próprio título do filme remete ao que seria a perspectiva de Seboipepe, afinal o saboroso francês era seu amante e ela o devorou nos dois sentidos da palavra "comer" na língua portuguesa (alimentar-se e fazer sexo). Esta cena tão literal quanto metafórica torna-se, na narrativa, um primeiro prenúncio (sexual) do canibalismo que encerrará o filme.

Na sequência seguinte, os tupinambás lançam-se no ritual de canibalismo e Jean resiste tal como instruído pela amante. Perto do final do ritual, Chimbabume, o chefe da tribo, prepara-se para deferir o golpe final; Seboipepe instrui Jean a dizer a frase ritual em tupi, mas ele a empurra e diz o que Ihe fora ordenado em francês: "Quando eu morrer, meus amigos virão para me vingar. Não sobrará nenhum de vocês sobre esta terra". Logo em seguida, num raccord para um plano de conjunto do alto, vê-se Jean ser golpeado e morto, o corpo sendo carregado pela aldeia para ser preparado enquanto os indígenas dançam ao seu redor. Na última sequência de imagens, planos intercalados mostram o chefe da aldeia correndo acompanhado pelos seus companheiros, segurando os canhões de pólvora que Jean ensinara os tupinambás a manejar; em novo raccord, Seboipepe é mostrada devorando um pedaço de carne humana (o pescoço de Jean?). Não a vemos colocando a carne na boca, apenas seu olhar e expressão feliz é mostrado. O canibalismo se realiza visualmente como ato final de alimentação.

Fica evidente que a apropriação das técnicas estrangeiras (o canhão com 168 Cunhambebe) é uma menção direta à antropofagia oswaldiana, de maneira que quando o filme se aproxima do canibalismo, ele o faz pelo prisma modernista. Contudo, o que era metáfora modernista virou ato literal ritual no qual a antropofagia era canibalismo. Nada alegórica essa cena produz um giro de sentido, como na ritualização encenada e sexual entre Seboipepe e Jean. Seu desvio restaura o sentido etnohistórico de ingerir carne humana, o ato canibal. Os olhos de Seboipepe mirando a câmera desviam de um princípio antropofágico modernista, afinal, aqui há uma metonímia ritual precária montada em dois atos "literais" (sexo e ingestão). A mirada de Seboipepe entrega a serenidade com a qual se delicia com a carne de Jean, num banquete que se sabe ritualizado para absorver a força do inimigo estrangeiro, mas o qual, recuado no tempo pela reconstituição etno-histórica da fita, entrega a ideia da história como uma visita a uma terra/tempo de selvagens. O ato antropofágico está informado a partir da alteridade indígena não como o bom selvagem, mas um selvagem inteligente mostrado na crueza de sua denotação encenada.

A antropofagia em Como era gostoso o meu francês, era, portanto, uma apropriação e transformação da memória cultural. Desloca o mito modernista por meio da imagem e do registro visual; deixa de ser metáfora incorporativa para na visualização fílmica ser ato de alteridade ritualizada. A ingestão ritual de carne humana é um "evento" que é difícil de representar/figurar 
cinematograficamente, pois enquanto "ato" mistura o literal (comer) com o figurativo (ritual). Fica evidente que o canibalismo e a antropofagia modernistas são figuras que oscilam entre distância e proximidade, violência concreta e metafórica, ato ritual e profano, excesso e normalidade, permitindo, como lembra Kiening (2014), a oscilação entre autentificação do estranho e estranhamento do próprio numa transferência de qualidades de um e um outro. Como era gostoso o meu francês ao girar a antropofagia no canibalismo, torna os atos do sexo e da alimentação tão fortes quanto os desvios que serviam à tematização da incorporação como brasilidade com base no modernismo. Nelson Pereira coloca-se como um herdeiro de Oswald e dos modernistas, participa também da tradição antropofágica, mas distancia-se na medida em que visualiza outro passado possível.

O final exato da fita é um plano de uma praia deserta, seguida por uma cartela em fundo preto no qual se lê: "'Lá no mar pelejei, de maneira, que nenhum tupiniquim ficou vivo. Estendidos ao longo da praia, rigidamente, os mortos ocuparam cerca de uma légua'. Mém de Sá, Governador Geral do Brasil, 1557". Este é o único momento em que uma fonte histórica convencional inverte o sentido da imagem. A vitória tupinambá com o sacrifício de Jean é seguida por um relato de um acontecimento histórico que se sabe efetivo, um documento da barbárie portuguesa (europeia), que aponta que mesmo que aquela tribo tenha vencido no enredo, a longo prazo, ela perdeu na história.

As interpretações sobre este texto de Mém de Sá são divergentes. Stam (1997) e Sladier (2012) consideram-na como uma interrogação sobre quem seria o bárbaro, o canibal ou o europeu que o mataram? Ao contrário, Lúcia Nagib (2006) vê o sonho frustrado de uma utopia de convivência circunscrita ao passado, perdida num tempo em que devorados e devoradores se entredevoravam ${ }^{12}$. Queremos, contudo, inserir a nossa desleitura ao lembrar que a leitura alegórica dos filmes históricos deste período era resultado de um movimento duplo: de um lado os enredos permitiam que o passado fosse apropriado como símbolo do presente, por outro, uma vez que a alegoria, desde os anos 1960, tornarase um recurso comum a filmes, cineastas e intérpretes de filmes (críticos de cinema e da cultura em geral), mesmo numa película não alegórica, tendiam no contexto de repressão política a gerar interpretações alegóricas.

Como era gostoso o meu francês apenas em suas sequências finais (descritas acima) torna-se uma alegoria antropofágica de fato. Parece-nos que mesmo as interpretações de Avellar e Fassoni, ao usarem o tropo antropofágico não o repetem simplesmente, mas o modificam, pois preveem que se trata de "devorar antes de ser devorado" (FASSONI 1972). Os atos sexo-alimentação funcionam como embaralhadores da consciência histórica do período. Comentando seu filme Macunaíma, Joaquim Pedro de Andrade afirmava em 1971:

[...] a película trata da permanência da antropofagia na sociedade brasileira. Isto resulta da constatação mais ou menos radical, de que,

\footnotetext{
12 Nagib aplica à fita de Santos o mesmo princípio de interpretação da antropofagia realizada por Joaquim Pedro de Andrade em Macunaíma.
} 
essencialmente, as relações entre as pessoas permanecem iguais deste os tempos em que realmente se praticava a antropofagia direta, simples e selvagem; até os dias de hoje, em que essa forma antropofágica ganha um aspecto civilizado, um aspecto industrializado (ANDRADE 1971, p. 23). ${ }^{13}$

Andrade concebe a antropofagia como modus operandi da sociedade brasileira e típica dos países subdesenvolvidos, sendo Macunaíma uma história "de um brasileiro devorado pelo Brasil" (STAM JOHNSON 1995, p. 82), uma autofagia na qual os fracos se entredevoram. Contudo, o próprio Avellar menciona Andrade para deslê-lo:

Todo consumo é redutível, em última análise ao canibalismo" - escrevia Joaquim Pedro de Andrade quando do lançamento de Macunaíma. "As relações de trabalho, como as relações entre as pessoas [...] ainda basicamente antropofágicas. Quem pode come o outro, por interposto produto ou diretamente.

Neste antropofágico manifesto [Como era gostoso...] [...] o que está proposto é a necessidade do colonizado comer duas vezes o colonizador. Primeiro comer sua tecnologia e, logo em seguida, devorá-lo numa alegre e colorida festa de carnaval. O que está proposto é devorar quem nos devora (AVELLAR 1972).

Trata-se de uma antropofagia original, distante e histórica, que serve como modelo e projeto diferente do presente autofágico de Joaquim Pedro e dos tropicalistas. Nem a interpretação de Avellar, contudo, consegue romper o limite que a antropofagia literal impõe ao princípio da identificação histórica. Nelson Pereira dos Santos reclamou que seu público se identificou com o francês (SALEM 1987), mas para o público (classe média brasileira), mesmo que busque no índio o vínculo telúrico com as origens do Brasil, ao mesmo tempo, reconhece o indígena como o diferente. O mesmo enredo que transforma o indígena em ícone de modelo de civilização faz de Jean uma vítima, pois, por pior que fosse o seu caráter, a impossibilidade de fuga, o fato de ser estrangeiro prisioneiro numa terra inóspita, e finalmente o fato de ser sacrificado, criava empatias involuntárias que realçavam o canibalismo como um ato extremo e hostil. 0 indígena transforma o colonizador em "objeto" criando uma oscilação entre o outro e o próprio. A imaginação antropofágica tem uma dimensão objetiva/ subjetiva, na medida em que o filme não apenas imagina o outro/eu ao qual objetifica (o indígena), mas o imagina como um outro sujeito que confronta e pode objetivar o europeu também.

Realizada no recuo da história, produz-se um sonho frustrado de país indígena cujos limites foi o comer de Seboipepe. Como um "sonho histórico" construído não apenas pelo recurso aos "elementos antropológicos", a fita entrega o pensável sobre o passado articulado para além dos tropos. Como era gostoso o meu francês propõe uma imagem/sonho visual da história, um

\footnotetext{
${ }^{13}$ A maior parte da bibliografia trabalha a linha interpretativa do filme Macunaíma.como alegoria antropofágica da sociedade brasileira: "em todo lugar prevalece a mesma lógica que nivela o 'primitivo' e o 'civilizado', a mata e a cidade, as lutas da natureza e as competições da cultura. Macunaíma-filme, neste sentido, a antropofagia como princípio de interação entre as personagens, regra da sociedade" (XAVIER 2005, p. 250; cf.: GUEDES 2011).
} 
projeto político indígena que, no final da fita, torna-se trágico, afinal a soberania nativa desaparecerá no horizonte da história conhecida pelos espectadores e invocada pelo próprio filme. As últimas palavras de Jean, proferidas em francês ("Não sobrará nenhum de vocês sobre esta terra") soam como uma maldição, assegurada como fato histórico pelo texto de Mém de Sá e pela memória cultural da "civilização brasileira". Como era gostoso o meu francês mostra um momento anterior à ruptura histórica. Num distanciamento histórico ficcional, produzido pelo ato canibal, a representação do passado foi entregue em sua estranheza temporal quando o Brasil não era ainda Brasil. O indígena é assim assimilado como tema do passado e reinserido na memória visual a partir da sua apropriação histórica.

Uma vez que Como era gostoso o meu francês é um filme histórico que apresenta o passado encenado como imagem visual, o devorar Jean é uma perturbação dos tropos convencionais, uma ampliação das oscilações fantasmáticas geradas pela antropofagia. O passado é deslocado pelo acontecimento da imagem e torna-se "outro", distante, necessitando do reconhecimento de sua alteridade. Os olhos brilhantes e fugidios de Seboipepe lembram ao espectador como era gostoso o seu francês, e ao deliciar-se na carne europeia perturba as certezas metafóricas antropofágicas, pois propõe uma dúvida: como um ato histórico extremo pode servir de modelo para um projeto político presente?

A antropofagia afirma-se e desafia-se ao mesmo tempo com um final ambíguo. A diferença temporal salta na alteridade histórica-etnológica garantida na presença da imagem fílmica que propõe acesso ao passado, na mesma medida em que assegura sua extrema alteridade. O indígena canibal vira ícone na sua ambígua relação com as narrativas visuais da brasilidade. Como era gostoso o meu francês narra um mito de origem que marca a queda original e assegura sua inalienável recuperação: explica porque os brasileiros não podem ser mais como os tupinambás, embora sejam seus herdeiros.

\section{Considerações finais}

A compreensão do uso público do passado nos filmes históricos dos anos 1970 pode se renovar se observarmos como as fitas pensam a história, o passado e o tempo por meio de um movimento duplo de aproximação e distanciamento temporal. Além das máscaras de passado que permitem abordar elementos do presente autoritário, Como era gostoso o meu francês realiza uma distância temporal e cultural assegurada pelo ritual antropofágico.

Tal perspectiva permite-nos levantar algumas hipóteses sobre a maneira como a produção da historicidade pelo cinema enfrenta questões que se atravessam mutuamente: (a) os membros do campo cinematográfico articulam usos dos vestígios históricos (chamadas de fontes/documentos pelos historiadores) os quais, podem servir de base para composição da encenação ou serem incorporados na obra como ocorre com as figuras de Bry na fita de Nelson. O (b) debate com as tradições interpretativas sobre o passado, pode envolver tanto aquelas produzidas pelo conhecimento histórico acadêmico como 
pelas outras formas de mídias, tais como a literatura, o cinema ou a pintura. No caso destas últimas, frequentemente, o encontro com a tradição se faz por meio de operações tropológicas e iconológicas, ou seja, o enfrentamento e deslocamento das imagens e metáforas já disponíveis que servem como base de interpretações históricas anteriores, das quais destacamos, no caso aqui exposto, a antropofagia.

Finalmente (c) a própria composição visual é um misto de imagem \& texto nos quais a historicidade torna-se visual e, por isso, está sujeita a graus variados de interpretação e ambiguidades. Por um lado, em Como era gostoso o meu francês a assume seu legado antropofágico, e, por outro, o filme foi interpretado como tal por críticos de cinema, jornalistas e acadêmicos. Contudo, como a película construía um estranhamento etnohistórico, circunscrevendo próprio/estranho (indígena-brasileiro) no passado e na alteridade, dá origem a níveis de ambiguidade que acionam várias possibilidades de interpretação. Os indígenas ofereceram uma alternativa política que não foi seguida e continua como proposta: "devorar quem nos devora". O significado desta sentença, contudo, estava aberto na época - e continua até hoje! Não é por acaso que José Carlos Avellar usou o pronome oblíquo "nos" para deixar evidente que o filme era, em sua interpretação, uma obra sobre a coletividade nacional, pois o canibal era o nativo (um brasileiro ancestral) e o francês, um estrangeiro. 0 passado prático foi convocado para compor a fatura do filme e pelos intérpretes da fita, de maneira que a memória e a experiência comuns foram mobilizadas para saber o que fazer para agir e entender como os artefatos restantes do passado (as figuras de Bry ou os relatos de viajantes) e construir possibilidades de como articulá-los com o momento histórico vivido na época da elaboração da narrativa fílmica.

Fica clara a presença da composição poética na segunda e terceira relações acima propostas na formação visual do passado como filme, a qual é realizada na mediação dos tropos da tradição, bem como a própria retomada desta se realiza na criação de uma nova imagem-tropo. A película é um ato de documentação de sua feitura, afinal, no mínimo, trata-se de um documento de sua própria realização - no caso do filme histórico, uma documentação da percepção do passado de um determinado grupo social. A questão, por assim dizer, mais historiográfica, é que Como era gostoso o meu francês elabora o distanciamento temporal que o conhecimento histórico acadêmico valoriza, mas move-se com as características da anacronia, o pecado original da historiografia.

Os usos visuais do passado implicam em compreender que as imagens "são tanto entidades verbais como visuais, tanto metáforas como símbolos gráficos. São, um e ao mesmo tempo, conceitos, objetos, figuras e formas simbólicas" (MITCHELL 2011, p. xvii) que podem tornar operativa a realidade sociopolítica e virar o que se pode chamar, convencionalmente, de ícones sociais, tais como o indígena antropófago na memória cultural brasileira. Quando Nelson Pereira dos Santos se aproximou do passado brasileiro, enfrentou-o a partir das algumas simbologias que o indígena, como ícone sociopolítico, possuía, abordando-o a partir da antropofagia. 
De um ponto de vista lógico, tanto uma metáfora como uma imagem são "categorias-erros" na medida em que são giros sobre o que se toma inicialmente como o mundo cotidiano. São as sobreposições entre os "erros" (desvios) e o cotidiano, que incorporam novos limites para a realidade, fazendo com que a imagem seja um instrumento de agenciamento do real e do passado, assim como ela própria, para fazê-lo, é agenciada pelos sujeitos (MITCHELL 2011). Interessa, portanto, estudar o processo pelo qual o tropo \& imagem (a antropofagia, por exemplo) tornou-se o sentido literal (a ingestão ou o sexo) e deste passou ao "figurativo" histórico (o passado nacional). A imagem do passado permitiu colocar em perspectivar o passado como diferença (o paraíso perdido do pré-Brasil colonial) e o presente como dotado de diferenças em relação a este mundo pretérito.

Graças ao olhar etnohistórico de Nelson Pereira dos Santos, Como era gostoso o meu francês explicita um passado possível por meio do canibalismo. O filme tornase assim um monumento no sentido original da palavra, um registro intencional da memória dos indígenas desaparecidos, um objeto/imagem intencional para a memória de um passado mostrado enquanto diferente (e frustrado) pela História. Se o monumento é um artefato dotado de valor de memória de dois vetores (RIEGL, 2014) que podem ou não estar harmonizados - um valor de ancianidade que aponta para a presença/resto do passado/tempo no presente e o valor histórico construído e enriquecido pela narrativa de passado à qual o artefato é vinculado - Como era Gostoso o Meu Francês articula vestígios enredados em imagens antropofágicas, funcionando como um ativador intencional do passado.

\section{Referências bibliográficas}

ANDRADE, Joaquim Pedro. Joaquim Pedro de Andrade por el mismo. Cine \& médios. Argetina, v. 2, n. 5, p. 21, 1971.

ARAÚJO, Valdei Lopes de. História da historiografia como analítica da historicidade. História da Historiografia, n. 12, p. 34-44, 2013.

ASSMANN, Aleida. Espaços da Recordação. Campinas: EDUNICAMP, 2009.

AVELLAR, José Carlos. Manifesto pau-Brasil. Jornal do Brasil, Rio de janeiro, 14 jan. 1972. Caderno B, p. 8.

BAECQUE, Antonine du. Camera Historica: the century in cinema. New York: Columbia University Press, 2012.

BLOOM, Harold. Um mapa da desleitura. Rio de Janeiro: Imago, 2003.

CAMPOS, Augusto de (org.). Teoria da poesia concreta: textos críticos e manifestos. São Paulo: Brasiliense, 1987

CHOAY, François. O Patrimônio em questão: antologia para um combate. Rio de Janeiro: Fino Traço Editora, 2011.

CHICANGANA-BAYONA, Yobenj Aucardo. Do Apolo de Belvedere ao guerreiro tupinambá: etnografia e convenções renascentistas. História, v. 25, n. 2, 2006. 
FASSONI, Orlando L. Antropofagia, um grande tema. Folha de São Paulo, São Paulo, 2 de mar. 1972. Ilustrada, p. 3.

FAVARETTO, Celso. Tropicália: a explosão do óbvio. 2007. In: BASUALDO, Carlos. Tropicália: uma revolução na cultura brasileira (1967-1972). São Paulo: Cosac Naify, 2007, p. 81- 96.

GAGNEBIN, Jeanne-Marie. A memória dos mortais: notas para uma definição da cultura a partir de uma leitura da Odisseia. In: . Lembrar, escrever, esquecer. São Paulo, 2006, p. 13-28.

GUEDES, Wallace Andrioli. Brasil Canibal: antropofagia e tropicalismo no Macunaíma de Joaquim Pedro de Andrade. Dissertação. Mestrado em História. Niterói, RJ, 2011.

GUIMARAES, Manoel Luís Salgado. Vendo o passado: representação e escrita da História. Anais do Museu Paulista, v. 15, p. 11-30, 2007.

JENIZZI, Jhanainna Silva Pereira. Antropofagia e tropicalismo: identidade cultural. Visualidades, v. 8, n. 2, p. 49-73, 2010.

LESTRIGANT, Frank. O canibal: grandeza e decadência. Brasília: Editora da UnB, 1997.

MENDONÇA, Paulo Knauss. Aproximações disciplinares: história, arte e imagem. Anos 90, v. 15, n. 28, p. 151-168, 2008.

MITCHELL, W. T. J. Clonning Terror: the war of images, 9/11 to the present. Chicago: The University of Chicago Press, 2011.

Teoría de la Imagen. Madrid: Akal, 2009.

MIRZOEFF, Nicholas. An Introduction to Visual Culture. New York: Routledge, 1999.

MORETTIN, Eduardo. A representação da história no cinema brasileiro (19071949). Anais do Museu paulista, v. 5, p. 249-271, 1997.

MORETTIN, Eduardo; NAPOLITANO, Marcos; KORNIS, Mônica (orgs.). História e Documentário. Rio de Janeiro: Ed. FGV, 2012, p. 179. 210.

NAGIB, Lúcia. A Utopia no Cinema Brasileiro: matrizes, nostalgias, distopias. São Paulo: Cosac \& Naify, 2006.

RAMOS, Alcides Freire. Canibalismo dos Fracos: cinema e história do Brasil. São Paulo: EDUSC, 2002.

RIEGL, Alois. O Culto Modernos dos Monumentos. São Paulo: Perspectiva, 2014.

ROCHA, João Cézar de Castro. Uma teoria de exportação? Ou: "antropofagia como visão de mundo". In: ROCHA, João César de Castro; RUFFINELLI, Jorge (orgs.). Antropofagia hoje? Oswald de Andrade em cena. São Paulo: É Realizações, 2011, p. 647-668. 
SANCHEZ-BIOSCA, Vicente. Um archivo insomne: producción y migración de imágenes. História Questões \& Debates, v. 61, n. 2, p. 79-103, 2014.

SADDI, Rafael. O parafuso da didática da história: o objeto de pesquisa e o campo de investigação de uma didática da história ampliada. Acta Scientiarum, v. 34, n. 2, p. 211-220, 2012.

SADLIER, Darlene J. Nelson Pereira dos Santos. Campinas: Ed. UNICAP, 2012.

SALEM, Helena. Nelson Pereira dos Santos: o sonho possível do cinema brasileiro. São Paulo: Brasiliense, 1987

SANTOS, Nelson Pereira dos apud MONTEIRO, José Carlos. Nelson Pereira dos Santos: realismo sem fronteiras. Filme e cultura, ano III, n. 16, p. 6-15, 1970.

SANTIAGO, JR., Francisco das C. F. Cinema e historiografia: trajetória de um objeto historiográfico (1970-2010). História da Historiografia, n. 8, 151-173, 2013.

.... E a etnologia fez os cineastas sonharem: olhar etnológico e alteridade no cinema brasileiro entre 1970 e 1980 . Boletim Museu Paranaense Emílio Goeldi, v. 9, n. 2, p. 417-443, 2014.

SHOHAT, Ella; STAM, Robert. Crítica da Imagem Eurocêntrica. São Paulo: Cosac \& Naify, 2003.

STAM, Robert. Tropical Multiculturalism: a comparative history of race in Brazilian cinema \& culture. Durham: Duke University Press, 1997.

STAM, Robert; JOHNSON, Randall. Brazilian Cinema: London e Toronto: associated University Press, 1992.

WHITE, Hayden. The Practical Past. Illinois: Northwestern University Press, 2014.

Trópicos do Discurso: ensaios de crítica da cultura. São Paulo: EDUSP, 1997. 